\title{
CUANDO LA MÚSICA SE CONVIERTE EN SUFRIMIENTO. JUEGOS DE (DES)AMOR E IDENTIDADES, TRANSTEXTUALIDAD, ANGUSTIA Y SUICIDIO EN DIABULUS IN MUSICA DE ESPIDO FREIRE
}

\author{
Samuel Rodríguez \\ Université Paris-Sorbonne, París, Francia \\ samuelmusicandart@hotmail.com
}

\begin{abstract}
RESUMEN/ ABSTRACT
Diabulus in musica (2001) de Espido Freire (Bilbao, 1974) nos brinda un "infierno musical" donde la música se convierte en objeto de displacer y canalización de la "enfermedad mortal" kierkegaardiana, esto es, la angustia. Además de la música, Espido Freire despliega otros recursos transtextuales como la mitología nórdica, el cuadro San Jorge y el dragón de Paolo Uccello y la tragicomedia El caballero de Olmedo de Lope de Vega. También nos sumerge en un peculiar juego de espejos donde nada es lo que parece: el (des)amor confunde el destino y las identidades de los personajes, abocados al sufrimiento y, finalmente, al suicidio. Para explicar estos aspectos, hacemos uso de una metodología multidisciplinar, fundamentalmente a través de fuentes narratológicas, filosóficas y sociológicas.
\end{abstract}

Palabras clave: Espido Freire, Diabulus in musica, música, angustia, suicidio.

WHEN MUSIC BECOMES SUFFERING. GAMES OF (DIS)AFFECTION AND IDENTITIES, TRANSTEXTUALITY, ANGUISH AND SUICIDE IN DIABULUS IN MUSICA BY ESPIDO FREIRE

Diabulus in musica (2001) by Espido Freire (Bilbao, 1974) offers a "musical hell" where music becomes an object of displeasure and a channel for the Kierkegaardian "sickness unto death", anguish. In addition to music, Espido Freire develops other transtextual resources as Nordic mythology, the painting Saint Georges and the dragon by Paolo Uccello and the tragicomedy El caballero de Olmedo by Lope de Vega. She plunges us onto a peculiar game of mirrors where nothing is what it seems to be: (dis)affection confuses the fate and the identity of the characters, bound to suffering and, finally, to suicide. In order to explain these aspects, we develop an interdisciplinary methodology, especially through the use of narratological, philosophical and sociological sources. 
KeYWords: Espido Freire. Diabulus in musica. Music. Anguish. Suicide.

Y si es así, si has vivido desesperado, lo que aparte ganaste o perdiste no cuenta absolutamente para nada, todo se ha perdido ya para ti y la eternidad no te reconoce como suyo ni te reconocerá nunca, o lo que es todavía más horrible, te conoce como eres conocido y te mantendrá bien sujeto, por tu mismo yo, en los brazos de la desesperación.

Søren Kierkegaard

Según nuestra hipótesis, Diabulus in musica (2001) de Espido Freire nos brinda un "infierno musical" donde la música se convierte en objeto de displacer y canalización de la "enfermedad mortal" kierkegaardiana, esto es, la angustia. Pero además parece transportarnos a un peculiar juego de espejos donde nada es lo que parece: el (des)amor confunde el destino y las identidades de los personajes, abocados al sufrimiento y, finalmente, al suicidio. Para desarrollar estos aspectos, haremos uso de una metodología multidisciplinar, fundamentalmente a través de fuentes narratológicas, filosóficas y sociológicas.

Antes de sumergirnos en la angustia y la muerte debemos analizar el trasfondo de las tramas novelísticas de Diabulus in musica en torno a los caprichosos juegos de (des)amor e identidades, que se confunden hasta desaparecer.

\section{JUEGOS DE (DES)AMOR E IDENTIDADES, DESTINO Y TRANSTEXTUALIDAD}

"De los amores felices nunca se ha sabido que tuvieran novela" (Martín Gaite 75). Y, en verdad, Diabulus in musica nos ofrece una historia ya contada, la de un trágico amor a tres entre Mikel, la protagonista y el actor Christopher Random. Sin embargo, su planteamiento resulta original:

Esta historia ha sido contada de muchas maneras, en muchas ocasiones, pero nunca con dos fantasmas. Son dos, sin embargo, los que la originan. Ha sido abordada de muchas formas, en momentos muy distintos. Comenzaría un día de marzo, si deseáramos respetar 
el tiempo del reloj y el orden de los sucesos. Para Christopher no llegaría hasta años después, en un invernadero, con un té acre y la azucarera tambaleándose en un extremo de la mesa vacilante [...]. Mikel sí sabría el inicio, sí sería el más fiel custodio del origen que me he esforzado por reconstruir, pero lo guardó celosamente, y no dejó sino pedazos que necesitaban una mente más hábil que la mía para ser interpretados.

[ ...] Pero no es mi versión la interesante, no muestra sino confusión, manoteos de ciego, acordes inconclusos; piezas rotas. Comenzaré por tanto esta historia cuando Chris la conoció, porque él es, de todos ellos, el fragmento esencial, el que vincula. El que cree tener la razón (17).

Esa "confusión, manoteos de ciego, acordes inconclusos; piezas rotas" se aprecia en la fragmentación estructural de la novela. No obstante, las tramas se enmarcan en una clara composición circular-omnipresente en la narrativa espidiana (ver Rodríguez, "Perversión y muerte..." 411-412)-pues comienza y termina del mismo modo, cuando Balder (Mikel) viene a por la protagonista (13-14 y 184). Si nos atenemos al desarrollo cronológico, la historia de (des)amor comienza con Mikel, un apasionado estudiante de chelo en el conservatorio de Bilbao, donde conoce a la narradora autodiegética, entonces una adolescente estudiante de canto, y cuyo nombre permanece en todo momento oculto. Mikel Henry Goienuri, como Gabriel en Irlanda (1998), es un ser oscuro, de ojos verdes, a caballo entre el mundo de los vivos y los muertos, marcado por una "red de venas que se traslucían bajo la piel y en los finos cartílagos" (82). Él la deja al cabo de unos meses, y en ese transcurso de tiempo, su padre le obliga a abandonar el chelo y estudiar Derecho. La protagonista disfruta de sus derrotas: "Yo me alegraba. Los corazones rechazados se sienten con derecho a la crueldad" (86). Pero lo vuelve a ver dos años después, más delgado, con el pelo muy largo y claro, más peligroso, más cautivador: "provocaba la misma atracción que ofrecía el abismo" (88). Se ha transformado en Balder el blanco, el protagonista (interpretado por Christopher Random) de la película Ragnarok. Se confirma entonces un pacto mefistofélico que la protagonista firmó desde el primer día que salió con Mikel/Balder ${ }^{1}$, en el que asume ser la sombra de su amado:

La fusión del Mikel real y el Balder cinematográfico se hace evidente en la novela mediante el uso de ambos nombres para referirse al mismo personaje. Por ello, nosotros emplearemos en ocasiones esta fórmula ambigua cuando aludamos a Mikel. 
- No has cambiado [...].

- No he encontrado por quién cambiar -contesté, y creo que en aquel momento hubiera gritado en busca de ayuda.

- ¿Cambiarías, si yo te lo pidiera?

Le sostuve la mirada.

- Dejaría de ser quien soy, con los ojos cerrados, sin pensarlo, si alguien me indicara qué ser (88).

Al igual que las protagonistas femeninas de muchos relatos de Espido Freire, Mikel/Balder seduce a su víctima: "sus planes se extendían entre una pared y otra como telas de araña, y me capturaron nuevamente" (89). La protagonista consiente someterse a su particular Lestat. Pero finalmente ella decide abandonarlo, pues "siento que no pienso por mí misma" (90), a lo que él arguye: “¿Qué tienes que pensar? Eres mía, y yo soy tuyo. Frente a los demás, y contra la vida [...]. No sabrás por dónde caminar sin mí. Tú sola no eres más que una voz buscando un instrumento" (91). La protagonista está herida mortalmente por su veneno: "hubiera cambiado mi vida porque suplicara más, porque no se diera por vencido tan fácilmente. Tal vez me había equivocado, tal vez no me quisiera y tan solo necesitara una marioneta a la que mover y con la que jugar a poseer el mundo" (91).

El pacto mefistofélico entre ambos ofrece una revisión perversa de la figura neoplatónica del Renacimiento - tan visible en Garcilaso de la Vega- en torno a los phantasmata sobre la figura de la amada, una imagen simbólica construida por medio de la imaginatio que llegaba a apoderarse del alma del sujeto amante. Esta figura se retoma con mayor violencia en la literatura romántica, especialmente en los relatos sobre vampiros. Y precisamente acabamos de ver el carácter vampírico de Mikel/Balder. No obstante, ya desarrollaremos que Balder, la figura del dios nórdico que la protagonista asocia a Mikel, no es en realidad Mikel, sino la construcción que la protagonista ha hecho a partir de su propia proyección en él: “-Mi pesadilla era él-le dije. -Entonces, él debes ser tú" (127) le responde a la protagonista la psicóloga que trató a Mikel antes de su suicidio. Lo mismo le sucerá más adelante con Chris. No en vano, estamos ante una narradora autodiegética que, al igual que en Irlanda o La flor del norte (2011), resulta infidente, es decir, manipula los hechos, los falsea, en parte debido al carácter inconsistente del personaje, pero es posible que también debido a un intento autoconsciente de jugar con espejos cruzados, según veremos en el último epígrafe. 
A este respecto, cabe destacar la simbiosis entre la fragilidad de la protagonista y la de la realidad que la circunda: la novela supone una incursión en la ambigüedad de una realidad fantasmal, que asume lo fantástico -la narración desde el purgatorio eterno- no solo como plausible sino como auténtico. La propia Espido Freire ha sostenido en múltiples ocasiones que "la novela española tiene una revolución pendiente: incluir elementos de fantasía [...]. Parece que la literatura fantástica es un pecado que se tiene que purgar a base de costumbrismo y realismo. La narrativa fabuladora solo se permite en la literatura infantil" (Arenas, "Entrevista a Espido Freire"). Pero la fantasía es también duda -“le fantastique, c'est l'hésitation" (Todorov 29)-. Se trata de la duda entre las apariencias, la supuesta realidad e irrealidad pues, acaso como sostuvo Nerval, "quoi qu'il en soit, je crois que l'imagination humaine n'a rien inventé qui ne soit vrai, dans ce monde ou dans les autres" (cit. en Todorov 44).

En este sentido, a Espido Freire siempre le ha gustado "jugar" con el lector (véase explícitamente en el caso del libro de cuentos Juegos míos de 2004). La manipulación se extiende por sus obras siguiendo la estela magistral de Julio Cortázar (Rodríguez, "Voces y espejos..." 55-61). De hecho, incluso hay una velada sugerencia al relato "Queremos tanto a Glenda" en Diabulus in musica, pero es indudable que otros cuentos como "Las babas del diablo" o "Continuidad de los parques" influyen en su arte narrativo, y esta obra no escapa a las citadas referencias. Así, no puede asegurarse nada por completo, en una obra en la que el juego de espejos deliberado maneja la ambigüedad a su antojo, sobre todo con respecto al final de su protagonista. Por otro lado, no debe olvidarse que todo lo que leemos (todo lo que oímos de su voz) es un canto de sirena, un canto de cisne agónico, de manera que todas las voces son su voz. El único momento de pluralidad bajtiniana en la novela se produce cuando la protagonista indaga acerca de las razones sobre el suicidio de Mikel. El resto de la novela, tal y como se ha indicado, parte del punto de vista de una voz narrativa infidente.

Así pues, retomando la relación tóxica entre la potagonista y Mikel/ Balder, tras el suicidio de éste, ella -carente de identidad propia- le sigue perteneciendo. Por él muere y Mikel/Balder arranca su corazón. Y por él, poco antes, tiende sus redes para atrapar a Chris:

¿Qué había que contar? ¿Qué era tan importante como para haberme marcado con hierro candente, como para haber impulsado a Clara a extender sus redes de araña (un profesor de Pablo amigo de Christopher, 
una fiesta, insinuaciones, suerte y paciencia), qué se había orquestado con tal precisión como para permitirnos acabar allí? (40).

Lo importante son las historias, su historia, la de Mikel/Balder y, en un lugar discreto, la suya: "La historia era el anzuelo, y yo no importaba. Pero quizás tampoco él [Chris] importara" (30), ya que "aquel hombre no estaba allí, porque había estado allí mucho tiempo antes, pero no podría decir qué parte de él era real y cuál imaginada" (28). El veneno de Mikel debió inducirla a la recreación del ser anhelado al tiempo que desconocido: "inventé a Balder: imaginé, con el placer extraño de crear un nuevo ser, un frankenstein hermoso compuesto de retales, a quien debía ser mi compañero, mi igual" (127). Por eso "de pronto tuve conciencia de que él no era Balder, de que tampoco yo era Balder, pero que de alguna manera los tres nos habíamos encontrado" (29-30). La historia de amor a tres ha comenzado: "Podría haber dicho Te amo. Podría haber dicho Te amamos, te amábamos tanto, y ahora eres real. Ahora puedes herir y defraudar, no quiero conocerte. No quiero que seas" (141). Pero nuestra protagonista persevera en su plan (el de Mikel) hasta que "el veneno había pasado a la sangre de Christopher" (47). Sin embargo, al igual que la joven de "Nuevas normas" (El trabajo os hará libres, 2008), cae en las garras de su propio juego de seducción hasta enamorarse de Chris y la sombra que perfila en torno a Balder. Como le sucedió con Mikel, se desprende de ella misma para fusionarse con él: "Deseé desaparecer, fundirme con él, fuera quien fuera, mientras me rescatara, mientras me dijera quién debía ser yo, mientras fuera capaz de mostrarme el absoluto y arrojarme luego de nuevo a la realidad de modo tan certero" (51). El amor, como el sexo, anhela saciar un vacío del sujeto que, según veremos, se torna imposible. Para Gianni Vattimo

el hombre de la sociedad del conflicto, en general, no tiene verdaderas relaciones con otros, porque para él la alteridad es solo un modo de reproducir afuera sus propios conflictos internos [...]. El amor entre los sexos constituye solo para el hombre del conflicto un modo de encontrar un remedio momentáneo para la necesidad, la soledad, la satisfacción (216).

En el caso de esta novela, "lejos de la liberación, el amor terminará transformándose para la voz protagonista en una trampa, en un encierro voluntario que anula cualquier interés y deseo fuera del propio amado" (Gómez-Elegido Centeno, "Voces y presencias femeninas..." 26). Chris 
además reduce su ya insignificante espacio propio: "odiaba la idea de que yo trabajara" (110). La relación empeora con los celos injustificados de la protagonista, que casi pierde la cordura al recrear durante semanas un simple escarceo de Chris antes de conocerla. La salida a esa "trampa" identitaria es para nuestra protagonista el suicido, que sella a muerte el destino de unos personajes unidos a la angustia por la eternidad.

Pero existen además otros elementos que interrelacionan a los personajes de esta novela. Los caprichos del (des)amor son el nexo de unión de los tres personajes, que entretejen su destino e identidades. Para la autora, el amor es en sí mismo un estímulo que reproduce, al igual que en el caso de la protagonista de Diabulus in musica, la primera experiencia amorosa, proyectada en los amantes futuros:

No se vive más amor que el primero: a partir de ahí, comienzan a amontonarse. De hecho, no se siente más amor que el primero, rememorado una y otra vez. En el amor buscamos convertirnos en inmortales, hacernos inolvidables para la otra persona, y muchas veces lo único que conseguimos es que el fantasma del amado no nos abandone jamás (Primer amor 23).

Así, la protagonista de Diabulus in musica se adhiere a Mikel. La fijación de él por Balder, su fantasma, marca a fuego el destino de su vida -incluso tras la muerte- y la de Christopher Random, el Balder "original". Pero Chris no es solo Balder, sino que vive a partir de los personajes de sus películas:

se había convertido en demasiadas personas a lo largo de los años; había prestado su rostro, su cuerpo, incluso su voz, había contemplado ante el espejo el modo correcto de caminar o de inclinar la cabeza para resultar encantador, había vestido tantas identidades que algunos le conocían por el disfraz, por sus personajes, y no habían oído su nombre (21).

Al final sabrá que Chris reproduce frecuentemente en sus conversaciones frases aprendidas de sus películas (47-49 y 171). Debe ser cierto, según se asegura en El mercader de Venecia, que "el mundo me parece lo que es: un teatro, en que cada uno hace su papel" (251), pero aquí ni siquiera ellos conocen su papel pues, en un particular juego de espejos que analizaremos más adelante, cada uno interpreta reflejos de identidades falsas. Es pues una incursión en la contingencia del sujeto, su fragmentación y, como veremos, en la angustia ante la búsqueda infructuosa de una identidad propia. 
Un aspecto fundamental que en esta novela sustenta las tramas es la transtextualidad. La película "Ragnarok" aglutina todos los ingredientes: el destino ineluctable del ocaso de los dioses que, al igual que en la mitología nórdica, no son eternos.

- ¿Sabes qué significa Ragnarok? -me preguntó.

- El ocaso de los dioses - contesté.

- El ocaso de los dioses - repitió él. Luego continuó-. Hace mucho tiempo. Casi quince años. Más.

- No -repliqué yo-. Te equivocas. Está ocurriendo ahora² (41).

El Ragnarok, "la batalla del fin del mundo, del último día" (Freire, Diabulus in musica 41), es la batalla que ellos mismos libran, reproducida más allá del tiempo y el espacio, primero en Bilbao, luego en Londres, trece años después. Es la batalla del dies irae de la cual, como en el paratexto del responsorio gregoriano inicial, deseamos librarnos ${ }^{3}$, pues "cuando la batalla terminaba no quedaba nada, ni cielo, ni tierra, ni dioses, ni gigantes. Ni débiles mortales supervivientes" (42). Según la mitología nórdica

el Ragnarök, el último combate entre los dioses del orden y las fuerzas del Mal, establece la idea arcaica de un fin general [...]; sin embargo, la regeneración universal que le sigue, no solo no es una versión del mundo anterior, sino que además, no deja de ser la expresión de una idea vertebrada sobre la evolución cíclica del universo, fundamentada bajo el mito del eterno retorno (Sierra del Molino 141).

2 Tal vez por influencia de la ópera de Wagner, se ha confundido el Ragnarök (ragna-, posesivo plural de reginn, esto es, dioses, y -rök, "prodigio, hado, suerte" (Page 63), es decir, "el destino de los dioses", con "el ocaso de los dioses" (de la palabra rokr que significa "ocaso"). Sin embargo, sí es cierto que el destino de los dioses nórdicos es su ocaso y la muerte, pero no el fin del mundo sino la destrucción del antiguo régimen de dioses en favor de uno nuevo, regenerado.

"Líbranos, Señor, de toda maldad, de todo pecado. Líbranos de Tu cólera. Líbranos de la muerte repentina y sin confesión, de las acechanzas del diablo, de la venganza, del odio, y de toda mala intención. Del ansia de fornicar, de los rayos y las tempestades; del azote de los terremotos, de la peste, del hambre y de la guerra. Líbranos de la muerte infinita" (9). El paratexto aparece primero en latín y después en su versión traducida. Se trata de un responsorio anónimo del Officium defunctorum utilizado a lo largo de los siglos por numerosos compositores como Tomás Luis de Victoria, Anton Bruckner, Giuseppe Verdi, Gabriel Fauré (cuyo Requiem interpreta la protagonista durante su formación musical), Igor Stravinsky o Krzysztof Penderecki. 
La película de Chris no incluye por tanto la regeneración posterior sino que se detiene en la destrucción total, en la nada. En el caso de la novela, paradójicamente cuando todo acaba empieza todo, la "muerte infinita", de modo que en Espido Freire el recurso al tiempo cíclico y el eterno retorno no implican regeneración sino la repetición ad infinitum del sinsentido. Al igual que Mikel, Balder era "el único que había muerto ya cuando comenzaba el fin del mundo. El más hermoso, y el más amado" (Freire, Diabulus in musica 41). Y es que Balder, hijo de Odín, es el primero de los dioses ases en morir, aunque también será quien lidere el nuevo orden tras la "batalla final". Como en la tragedia y las novelas de Espido Freire, su destino es inevitable. Loki, envidioso de Balder, es el cerebro del asesinato. Pero es su hermano Hod, engañado mediante argucias por Loki, el ejecutor inocente. Así, "la muerte de Balder es necesaria, pues tiene que resucitar junto con Hödr después del Ragnarök para presidir el nuevo mundo regenerado" (Sierra del Molino 134). Como Balder, Mikel mueve los hilos del mundo más allá de la muerte. Y, como en la novela, subyace en el Ragnarok una cuestión de orden moral, la lucha necesaria entre el bien y el mal, el orden y el caos, pues si Balder representa el bien, Loki es su opuesto al ser el "dios del Mal [...]. Loki podría ser el elemento del equilibrio imprescindible en un mundo regido por la ley, el orden y el derecho; dado que en este universo mental los principios fundamentales son dicotómicos, construidos por pares adversativos" (Sierra del Molino 131).

Esa misma dicotomía se refleja de modo interdiscursivo en San Jorge y el dragón (1470), el cuadro de Paolo Uccello que la protagonista observa en la National Gallery de Londres:

Me gustaba también Uccello, cómo su San Jorge caballero implacable destrozaba al dragón que mantenía presa a la princesa, y cómo ella continuaba en su lugar, digna y erguida, hasta que aquella lucha hubiera terminado [....]. La muchacha de Uccello era tan inhumana como la luz de la luna en el cuadro diurno, como la concentrada saña de San Jorge, o el irregular patrón del césped que los rodeaba. Junto a ellos el dragón, con sus ocelos de mariposa en las alas, se arrastraba por el suelo, herido, inevitablemente enternecedor ${ }^{4}(22)$.

$4 \quad$ El cuadro es además, por elección de la autora, portada de la novela, si bien aquí solo se toma un detalle de la mitad izquierda del cuadro, dejando fuera al supuesto héroe, 
Frente a la clara división entre buenos y malos del Ragnarok o el cuadro San Miguel y el diablo Bermejo (1468) del pintor Bartolomé Bermejo, que también resulta del agrado de la protagonista (22), aquí el dragón se convierte en una víctima sádica de un héroe que no es tal cosa sino más bien un "santo" agresor, y la princesa de cuento de hadas, lejos de ser frágil, parece una gélida (y maléfica) dominadora. La propia autora señala que "son tres los personajes, como los de mi novela, pero con los roles invertidos. La dama posee al dragón, el caballero cumple con su deber con auténtica saña, y el pobre dragón sangra y muere: como los tres personajes de Diabulus" (Henseler 251). Así, Uccello, del mismo modo que Espido Freire, da un giro imprevisto a los clichés morales. La lanza asesina divide la composición en dos espacios irreconciliables: san Jorge a la derecha (y el deus ex machina en forma de torbellino), el dragón y la princesa "liberada" a la izquierda. Aunque el tema sea de origen cristiano -en realidad un mito atemporal- la obra parece extraída de un cuento de hadas (Davies 316), si bien, al igual que Espido Freire, huye del maniqueísmo y plantea la duda, la ambigüedad irresoluble de fuerzas necesarias (ver Rodríguez, "Hacia los orígenes del mal..."142-144).

Además del mito del Ragnarok y San Jorge y el dragón, Espido Freire se sirve a nivel metatextual de la obra de teatro El caballero de Olmedo (1620) de Lope de Vega para reflexionar sobre este conflicto de fuerzas. Chris será el protagonista de una nueva producción de la tragicomedia, y ella colabora en la escenografía junto con Stephen, amigo de Chris y escenógrafo. En apariencia, don Alonso es el apuesto caballero - un nuevo San Jorge- cuya bondad seduce al tiempo que genera envidias asesinas, y don Rodrigo es el asesino -el dragón- ajusticiado. Mas, ¿por qué muere don Alonso? Chris piensa que "alguien tiene que morir" (162). Stephen plantea que don Alonso debe morir puesto que es el "divino": "Don Alonso cae porque la perfección no puede tolerarse en un mundo ordenado. Es el cordero sacrificial. Solo la inmolación del elegido, y el ajusticiamiento de quien lo mata permitirán que brote una nueva primavera" (162-163), tal y como sucede con Balder según la mitología nórdica. Pero la protagonista plantea una teoría opuesta:

san Jorge. Esto no debe ser casual puesto que no hay héroes en la narrativa espidiana sino "monstruos" y personajes femeninos que se relacionan de modo ambiguo con ellos. 
Tal vez Alonso sea el elegido, pero no el divino. Alancea toros, como San Jorge al dragón, como San Miguel al diablo, pero es a su vez atravesado por Don Rodrigo. Y mediante el fuego, no mediante el acero. Un disparo. Don Rodrigo es el caballero que mata en último lugar. Puede que a la bestia. Los avisos que recibe Don Alonso, la canción espectral, la visita del fantasma, podrían pasar perfectamente por advertencias del demonio. ¿Por qué iba Dios a alertar a los suyos del peligro mediante nigromancias y presagios? Podría enviar a San Gabriel y anunciarlo abiertamente. El diablo cuida de los suyos. Don Alonso es el fantasma (163).

Stephen arguye que "Don Rodrigo es ajusticiado de una manera infamante" (163), pero ella lo cuestiona recurriendo a la mitología nórdica: "En el norte, los adoradores del Sol y de Odín se ahorcaban ritualmente de robles y vigas. La luz y la oscuridad se enfrentan y vence la luz, Alonso muere de noche: y Rodrigo de día" (164). Entonces piensa en Balder (Mikel), su particular héroe trágico que, del mismo modo que don Rodrigo, afronta con valentía las tinieblas del destino. Los papeles, como en el cuadro de Uccello, parecen invertidos. Chris no interpretará sin embargo a don Rodrigo, acaso el auténtico héroe, sino a don Alonso, de modo que el triángulo metaliterario queda cerrado y los papeles de los personajes definidos, siendo doña Inés -nuestra protagonista- la pobre damisela entre dos caballeros en lucha.

Además del Ragnarok, San Jorge y el dragón y El caballero de Olmedo, el destino y las identidades cruzadas poseen otro nexo común transtextual, más sutil, más evocador, más destructivo y angustioso: la música.

\section{CUANDO LA MÚSICA SE CONVIERTE EN SUFRIMIENTO}

En la narrativa de Espido Freire la música aparece en claro diálogo interdiscursivo con el texto literario a través de la interacción de formas (sonata cíclica, tema con variaciones), leitmotive y texturas, construidas con frecuencia en un claro dialogismo bajtiniano de voces narrativas entretejidas pero independientes, a modo de "polifonía textual" (García Galiano 460). Pero es en Diabulus in musica donde se hace explícita la experiencia musical de Espido Freire como soprano en el repertorio de la música antigua. La autora ha reconocido que la idea de una novela sobre la música le rondaba desde la niñez, 
alrededor de los catorce, cuando estudié el concepto del Diabulus. Quería una historia con un suicida, una fascinación que me acompaña de antiguo, y analizar cómo los muertos pueden continuar presentes cuando han fallecido en circunstancias extrañas, como se decía de los vampiros. Quería que la protagonista hubiera vivido en contacto con un mundo frágil y basado en apariencias, el ballet, o la gimnasia rítmica, pero al fin decidí que aprovecharía mi experiencia musical. Y de pronto todo tuvo sentido (Henseler 254).

También observamos aquí, al igual que en otras de sus obras, su fascinación por el chelo, un instrumento que la autora considera evocador por sus implicaciones físico-psíquicas, al ser ejecutado mediante un "abrazo" donde intérprete e instrumento se funden en un único ser (Freire, "El mal en mi obra" 2015). Pero ese abrazo puede ser trágico. Mikel se ahorca a la manera de los seguidores de Odín, sobre un círculo de velas junto a su chelo roto cuando su padre le prohíbe estudiar música, y la protagonista vive atormentada solo para la voz durante años. Y es que la música, el arte, exige sacrificio, dolor. Exige víctimas:

Se canta como se sangra. No existen más trucos: sin sangre, sin alma, el mejor oído, la disciplina más feroz, la técnica más depurada, se estrellan, como las notas, contra el vacío. Quien canta se enfrenta a una enfermedad terminal, a una hemofilia. Es, por tanto, una enfermedad sagrada, una enfermedad de reyes, como la locura; se venera a quien es capaz de sacrificarse en aras de la belleza, del servicio a los demás, del arte.

Una hermosa voz recibe las mismas ofrendas que se le brindaban a los dioses: fuego, alimentos, oro, fama. En ocasiones, vidas humanas. A mí se me entregó en ese altar, con la garganta palpitante, pronta al sacrificio, a los once años. No hubo sustitución divina, ni cierva ni carnero providenciales aparecieron para salvarme. Mi sacrificio debió hallar gracia a los ojos de los dioses, y asintieron, sonriendo. Entonces comencé a sangrar (65).

Pero la música, el arte, podría ser acaso un baluarte contra la angustia. Según la autora

la relación de la narradora con el mundo está basada en la dependencia, en la necesidad de que la dirijan o la narren, que le expliquen su lugar en la vida. El arte sirve para enmascarar esa carencia, hasta que su propio devenir le impide mantener la farsa. En mi caso, la música es 
principalmente un estímulo para escribir. Y el arte, una de las formas de hacer soportable una vida que en ocasiones observo con lucidez bastante dolorosa (Henseler 254).

La música le ofrece a la protagonista el poder de evocar otros mundos, otras vidas que escondan la angustia. Sin embargo, en palabras de su amiga Clara, la música, como los hombres, "no te librará de la angustia; en el peor de los casos, ni siquiera de la soledad" (109). De hecho, la música, más que un baluarte contra el abismo existencial, es, al menos en la novela, una ramificación de la angustia que desarrollaremos más adelante: "Aquella voz, mi voz, era la de una niña de amplias zonas ocultas y de tristezas insondables" (77). La música es incapaz de liberarnos de la "muerte infinita" del dies irae. Pero frente al caos, la música puede ofrecer armonía y tal vez sea cierto que, según el poeta, "rendidos y dominados por la armonía [...] Orfeo arrastraba en pos de sí árboles, ríos y fieras; porque nada hay tan duro, feroz y selvático que resista el poder de la música"5 (Shakespeare 313). Tal vez sea cierto también que "el hombre que no siente ningún género de armonía, es capaz de todo engaño y alevosía, fraude y rapiña: los instintos de su alma son tan oscuros como la noche, tan lóbregos como el Tártaro" (Shakespeare 313). Pero ¿y si la música fuera en sí misma un engaño, una trampa que seduce los instintos y nos arrastra a la angustia?, ¿puede acaso la música esconder la simiente angustiosa, disfrazada entre velos cautivadores? La respuesta es el diabulus in musica ${ }^{6}$ :

Cuando me acercaba a los principios de la música antigua me sentía desbordada: las teorías se contradecían entre sí y había que tener en consideración la ciencia medieval y la filosofía teocéntrica y las matemáticas [...].

Lo único que me había quedado claro y se había enganchado a mi mente como una rémora desde el primer día era que había que evitar las cuartas aumentadas. Que al componer había que desconfiar de la nota $\mathrm{Si}$, la séptima nota, porque, a poco que nos descuidáramos, podíamos romper el orden: podía aparecer el diabulus in musica.

\footnotetext{
Son palabras de Lorenzo en El mercader de Venecia.

Nótese que en la novela se produce un cambio vocálico de este concepto, comúnmente conocido como diabolus in musica (denominado así por Johan Joseph Fux en Gradus ad Parnassum de 1725). Nosotros emplearemos la misma forma elegida por la autora.
} 
Lo defendían todos los grandes nombres: Guido D’Arezzo en el Micrologus, Ramos de Pareja, en Musica practica, Francón de Colonia en Ars cantus mensurabilis, el mismo Monteverdi cuyos madrigales yo cantaba. En la escala musical, que los griegos habían intentado depurar, se había deslizado una irregularidad, un error. Un intervalo no regido por las matemáticas, el recordatorio de que, por mucho que el hombre creara, era mortal y limitado (79-89).

En un sistema de apariencia perfecta, armónica, se desliza la disonancia prohibida que nos angustia. Mas el problema del diabulus in musica, esto es, el intervalo de cuarta aumentada, el tritono, va más allá. Nuestro sistema musical de doce notas se basa en el círculo de quintas justas, esto es, de tres tonos y un semitono (fa, do, sol, re, la, mi, si, fa\#, do\#, sol\#, re\#, la\#, mi\#, si\#). Si tomásemos de modo matemático la altura de los sonidos habría un desequilibrio, lo cual tiene que ver con la acústica:

toute note musicale est une vibration, dont on peut mesurer la fréquence. Plus la fréquence est élevée, plus la note est aiguë. Le diapason actuel exige, par exemple, que le la 3 du milieu du clavier corresponde à la fréquence de $440 \mathrm{~Hz}$ [...]. L'intervalle qui sépare deux notes peut donc s'exprimer sous forme de fraction. Ainsi, l'octave se définit par un rapport de 2/1: le la2, inférieur à celui du diapason actuel, sonne à $220 \mathrm{~Hz}$ (Brossard-Deconinck 252).

Los otros intervalos se pueden expresar en relaciones numéricas simples: la quinta (3/2), la tercera (5/4) y la cuarta (4/3). Sin embargo, matemáticamente es imposible cerrar de manera perfecta el círculo de quintas, pues doce quintas corresponden a $(3 / 2)^{2}$, aproximadamente $129,7 \mathrm{~Hz}$, mientras que las octavas, en un sistema "perfecto", deberían dar $2^{7}=128 \mathrm{~Hz}$. De este modo, una serie de quintas acústicamente puras que comiencen en do no nos llevará a la misma nota sino a un si bemol. Por eso el círculo de quintas es en realidad una espiral. En consecuencia, ningún acorde está "afinado" en un instrumento de tonos fijos en la música occidental. Por el contrario, en el temperamento igual (empleado desde el siglo XVIII a partir de Jean Philippe Rameau y aún vigente) todas las quintas están ligeramente reducidas y las terceras mayores falseadas con el objetivo de igualar los doce semitonos de la octava, de manera que las tonalidades diferentes sean uniformes. En música, como en la vida, "il faut tempérer la difficulté, trouver une solution de compromis acceptable" (Brossard-Deconinck 251). Necesitamos (auto)engañarnos, crear un sistema de mentiras y paradojas convertidas en doxas sin ser conscientes de que, 
como en el sistema temperado, no es más que una falsedad de apariencia ordenada. Pero el diabulus permanece y la contradicción se hace necesaria.

El diabulus in musica nos recuerda por tanto nuestra naturaleza contingente que, con tanto empeño, nos hemos esforzado en proyectar en los demás $\mathrm{y}$, en el caso de esta novela, esconder tras máscaras ajenas. Mikel y ella sellan su unión bajo los designios de este intervalo prohibido: “¿sabes tú qué es el diabulus in musica?" (83) pregunta ella, y él responde: "No tengo ni idea. ¿Es importante?” (83). Sin embargo,

levantó la mano y dijo adiós. Yo fui incapaz de moverme. Sentí un temor agudo, una sensación de amenaza que descendía por mi espalda. En las articulaciones de sus dedos, con boli negro, había trazado la mano guideana [sic], las notas mágicas que determinaban en qué tono cantar. Y en la palma, en rojo, un pentagrama muy corto en el que podía leer Fa y Si. Una cuarta aumentada. Diabulus in musica ${ }^{7}(83-84)$.

Mikel está marcado por el diabulus in musica, y a él se ofrece cuando le cierran las puertas de su dolorosa pero necesaria "enfermedad sagrada". También él estableció un pacto mefistofélico, pero con la música. No obstante, la protagonista sí abandona la música: "yo ya veía con toda claridad que enloquecería si continuaba cantando. La disciplina, los ademanes despectivos de mi profesora, la invencible indiferencia que yo sentía frente al público que me escuchaba me resultaban insoportables" (87). La rivalidad es extrema, y sus compañeras la acosan. De hecho, "medio año más tarde una de las bailarinas de la compañía también la abandonó. Le habían metido cristal machacado en una de las zapatillas" (68). En el particular juego de espejos que es el teatro -como la vida de los personajes- ella se esfuerza en aportar su propia contribución: "Jamás quise ser cantante, aunque intenté ser, al menos, una mentirosa convincente" (95). Cuando abandona la música la máscara de los personajes cae, y el sinsentido -siempre presente- cobra de nuevo protagonismo:

Se esperaba tanto de mí. Una sirena puede entregar su voz a cambio de las piernas que le lleven al príncipe, pero ha de conservar la cabeza

\footnotetext{
La mano guidoniana fue imprescindible en todos los libros de texto musicales del Medievo, pues era un recurso mnemotécnico que permitía localizar las notas de la escala diatónica, especialmente los semitonos mi y fa, situados en las cuatro esquinas del polígono que comprende los cuatro dedos (Grout y Palisca 92).
} 
en su lugar. En las antiguas leyendas, las hadas poseían un hueco en la columna vertebral: un espacio que demostraba que no eran reales, que en ese vacío debía haberse alojado un alma. La voz de la sirena era su alma. Cuando calló, fue una princesa más. Yo callé. Entregué mi voz a cambio de encontrar la paz (95).

Pero no halla la paz. Sigue marcada por el diabulus in musica transmitido por Mikel y que, junto con su formación musical -su único reducto propio-guarda en secreto. Es un pacto mefistofélico que inicia Mikel y se perpetúa en los eslabones que le siguen: ella, Chris. Al igual que la Sirenita la protagonista lo abandona todo, primero por la música, más tarde por Mikel y, finalmente, por Christopher Random. También ella, en lugar de convertirse en espuma de mar, de disolverse en la nada, elige la muerte eterna (ver Rodríguez, "Le conte de fées comme catalyseur du mal..." 8-9).

El diabulus in musica no tiene implicaciones únicamente temáticas en esta novela sino estructurales. Las constantes anacronías, dispuestas como retazos de un universo en caos, cuestionan también el supuesto orden (narrativo) ficticio. De ello se ocupa su narradora autodiegética infidente. Además, el espacio-tiempo de toda la novela (o el no-tiempo y no espacio, ya que tratamos con fantasmas en su purgatorio), que le permite a la autora desarrollar esa compleja voz que nos perturba a su vez, solo puede abrirse mediante el hechizo, el embrujo. Puede tratarse de una palabra que a nosotros, los lectores, nos haga pasar a esa otra dimensión, la literaria, en que estos códigos que nos muestra la autora adquieran el sentido que les otorga la ficción. En otras obras puede ser una imagen (Alicia descendiendo por la madriguera, en que pasa de la realidad al mundo de fantasía) o una palabra que invoca la apertura de ese espacio de ficción. En el caso de Diabulus in musica se trata de las citas a modo de paratexto con las que se preludia la narración: el ya citado responsorio gregoriano del Officium defunctorum y el himno a San Juan Bautista ${ }^{8}$. Mediante su explícita recitación, el lector ya

8 En el siglo XI, el monje Guido d'Arezzo, para ayudar a recordar a los cantantes el diseño de tonos y semitonos de los seis grados musicales existentes, tomó un himno preexistente, Ut queam laxis (probablemente de al menos el año 800), al que él puso música. La primera sílaba de cada una de sus seis frases coincide a su vez con el orden ascendente de las notas, que se convertirán a partir de entonces en el nombre habitual de las notas (con la excepción del ut, sustituido por la sílaba do debido a su más fácil pronunciación). Espido Freire se preocupa de ofrecérnoslo como paratexto: Ut queam laxis/ Resonare fibris, / Mira gestorum, /

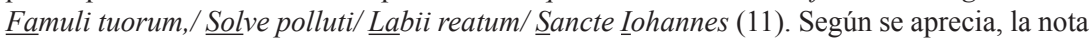


se encuentra en el espacio ficticio, ese en el que el orden es suceptible de ser alterado por el diabulus in musica. De esta manera, el lector queda también atrapado en la posibilidad del caos.

El diabulus in musica, el intervalo prohibido que se desliza dentro de una construcción temperada que falsea la realidad, nos aterra, pues pone al descubierto nuestro particular juego de medias verdades y mentiras que sustenta la existencia, ya que "el mundo pequeño de cada día sería escasamente soportable sin nuestra ración de mentiras cotidianas" (Freire, Donde siempre es octubre 15). El diabulus in musica es el intervalo discordante, paradigma de la síntesis contradictoria que somos. La música, según Settembrini, "es de naturaleza ambigua. No me excedo al calificarla de políticamente sospechosa" (Mann 230). Y esto es así porque, pese a su apariencia ordenada, se sustenta en la ambigüedad, tal y como se nos explica en Doctor Faustus: "La música es la ambigüedad erigida en sistema. Toma tal o cual nota, podrás comprenderla de una u otra manera, según sus relaciones. Considérala como aumentada a la derecha o disminuida a la izquierda, y puedes, si eres astuto, usar a tu sabor de ese doble sentido" (Mann 1019). A través de la séptima nota, el si, se introduce la duda, la sospecha. El siete es el número divino, la perfección y, sin embargo, en música es el lugar por donde se cuela el diabulus. Orden y caos, eternidad y contingencia, bien y mal, Balder y Loki, san Jorge y el dragón o don Alonso y don Rodrigo se funden en un abrazo trágico. Porque la música, paradigma de la ambigüedad, abre las puertas al temible abismo existencial, a la angustia.

\section{ANGUSTIA Y SUICIDIO}

La angustia ante el abismo existencial, ante la intuición del caos que subyace en la apariencia ordenada, mueve las tramas de una novela donde el suicidio se convierte en una respuesta insatisfactoria, incapaz de aplacar el sufrimiento. Así pues, es necesario estudiar en primer lugar el caso de la angustia y la femineidad y, finalmente, el suicidio como contestación a la angustia.

Diabulus in musica es una novela introspectiva, más allá del diario íntimo o el monólogo interior (ver Pozuelo Yvancos 100-101). En ocasiones resulta,

si -al igual que nuestros peores demonios- es “innombrable”, y se utilizarán finalmente las iniciales de Sancte Iohannes. 
al igual que su protagonista de nombre desconocido, inconsistente (ver García Jambrina 10 y Rodríguez Fisher 8), tal vez como reflejo del sujeto contingente, que reconstruye mediante jirones historias oscilantes en el tiempo y el espacio. Del mismo modo que en Irlanda, su narradora es autodiegética (ver Rodríguez, "Trauma y opresión..." 349-350). La protagonista también inicia un viaje, en este caso a Londres, para buscarse a sí misma o más bien a Balder, a Chris, el espectro de Mikel. Su profunda timidez recuerda a la de la joven Natalia en Irlanda. También su introspección parte de la adolescencia. Es entonces cuando se configura nuestra personalidad y tomamos conciencia de la imperfección del mundo y de nosotros mismos, cuando el diabulus se desliza lenta pero peligrosamente y comienza a jugar. La protagonista no revela su nombre porque aspira a construir una identidad propia a partir de la ajena:

Yo era yo. Eso importaba poco, porque nunca había encontrado ocasión para ser otra cosa. No sabía quién era, salvo que alguien me lo indicase, salvo que se cruzara en mi camino una personalidad lo suficientemente fuerte como para darme nombre, sentido, carácter. De otra manera, no era sino una colección de rutinas (20).

Por eso, "cuando perdí a Balder, perdí el mundo. Perdí, por tanto, mi lugar, mi nombre" (118). El abismo se abre más que nunca tras el suicidio de Mikel/Balder:

Mientras él volaba en el espacio, mientras se alejaba, atraído de manera inevitable por el centro de gravedad, nosotros nos empeñamos en continuar un viaje en el que él había introducido la duda. La sospecha. Con el tiempo, con la desesperación, con el agotamiento, nos dimos cuenta de que en realidad había brindado la certeza de que no cabía esperar recompensa al buen comportamiento, de que la vida era, irremediablemente, injusta (94).

Cuando está sola, utiliza el espejo para encontrarse o, tal vez, perderse en él: "Me pierdo en el espejo, me busco en el espejo" (20). En otra ocasión reconoce que "a menudo me sentaba en el borde de la bañera, con los pies descalzos enterrados en la velluda alfombrilla violeta, frente al espejo, y estudiaba mi rostro hasta que los rasgos se desdibujaban y terminaba observando algo mucho más allá de mí” (21). Más adelante confiesa:

Si me hubieran gritado a la cara, no hubieran hecho más patente mi soledad. En otras ocasiones no hacía nada, no escuchaba nada; miraba 
el reflejo en el cristal, como a veces me veía invertida en el espejo. Me gustaba mantenerme triste, mi mentón bajaba un poco, los ojos se agrandaban, y me transformaba en algo lejano, algo que habitaba un lugar que no era el cristal, ni la calle al otro lado (37).

Además de éstas y otras referencias, anuncian una exposición sobre espejos en la National Gallery, que visita con frecuencia. Y es que no solo a través del espejo, sino de la pintura, busca respuestas o, al menos, un "reflejo" amigo. Para Montserrat Linares,

her obsession with identity can be observed in this novel in the recurrent presence of mirrors, which serve as the place in which she seeks herself. She desires not only to recognize herself in them physically but also to find an existence that goes beyond her body. The only reflection she encounters is that of her loneliness (216).

Así pues, "for the protagonist, the mirror becomes an object that duplicates her inexistence. The mirror also introduces the theme of the double, of identity as fragmentary and fragmented" (Linares 216). Ya dijimos que todos los que supuestamente le dieron una identidad son imitadores de otros que a su vez imitan a otros: Mikel a Balder, la protagonista en su adolescencia a sus heroínas operísticas y, más adelante, a Mikel y a Christopher, y Christopher, a su vez, a todos sus héroes de ficción. Estamos ante un posible doble subjetivo externo: el yo repetido o desdoblado en otro, en un ser exterior diferente con el que se identifica el yo del personaje (ver Herrero 27). Ella vive a través de todos ellos, hasta que es consciente de que su última máscara, Chris, es como ella, otra máscara sin identidad que incluso intenta robarle su historia para hacer una nueva obra de teatro (Freire, Diabulus in musica 175-176). Por tanto,

si Christopher no era, no respondía a lo que yo había imaginado, a lo que durante años habíamos imaginado Mikel y yo, si no hacía sino moverse debido a la energía de un guión, de otras palabras, yo, marioneta de otra marioneta, no existía. Una vez más, yo no era yo. O, mejor dicho, yo era yo: pero aquello carecía de importancia, porque no era nada sin él. El mundo, el orden, se había quebrado. Tal vez siempre había sido así, un eterno diabulus in musica, y yo no había reparado en ello [...]. Menos aún él, que tampoco era él (173-174).

Ana María Gomez-Elegido Centeno considera que en esta novela cobra protagonismo "la ambigüedad y versatilidad en la existencia del hombre, 
el carácter impredecible de la vida que desata las posibilidades, entre las cuales está la del abismo y el vacío" ("Las huellas de la posmodernidad..." 256-257). En consecuencia, aquí "life is no more than a succession of mirrors that reflect each other" (Linares 217).

Y es que, si la música es una "enfermedad terminal, sagrada, de reyes", lo que subyace en Diabulus in musica es la "enfermedad mortal" kierkegaardiana, esto es, la angustia en tanto que abismo ante un nuevo juego especular: la posibilidad de la posibilidad o el "vértigo de la libertad", que "surge cuando [...] la libertad fija la vista en el abismo de su propia posibilidad" (Kierkegaard, El concepto... 61). El abismo invisible nos atrae y, aunque bien pudiéramos apartar la mirada, no lo hacemos pues el abismo es el lugar en el que (re) conocerse como seres contradictorios. Pero la mirada al abismo debe servir para reforzar al sujeto. En caso contrario puede convertirse, tal vez como nuestra protagonista, en hipocondríaco (Kierkegaard, El concepto... 159) o, aún peor, perderse a sí mismo en la desesperación, que Kierkegaard vincula particularmente al sujeto femenino y que, tal y como apreciamos en nuestra protagonista, se basa en "no querer uno ser sí mismo o la desesperación de la debilidad" (El concepto... 84), puesto que

la esencia de la mujer es la entrega, el abandono; y no hay femineidad donde no haya eso [ ]. Un hombre también se entrega [ ]; pero el yo del hombre no es el abandono [ ] ni tampoco se puede afirmar que el hombre alcance su yo mediante la entrega, como en cierto sentido es lo peculiar de la mujer (El concepto... 84-85).

Aunque no compartimos su opinión, en el caso concreto de esta novela la protagonista sí intenta construir su "yo" mediante la entrega y el abandono de sí misma a través de los hombres. No obstante, tampoco los demás personajes escapan al infeliz abismo: Mikel y Christopher también existen a partir de los demás; Clara busca a alguien a quien aferrarse; Karen, la exmujer de Chris, confiesa que "cuando no estoy enamorada, estoy muerta" (40); Silvia, hermana de Mikel, planeó suicidarse con su hermano; la madre de Chris, Lilian, parece escapar a la angustia, pero simplemente la rehúye con normas impostadas. Ni siquiera la pequeña Frances, la hija de Chris, escapa a ella, y todos viven en la infelicidad. Tal vez para no perpetuar la angustia, la protagonista decide no tener hijos: "alguien me dijo, hace mucho tiempo, que yo no tendría hijos. Ahora sé por qué. Ahora entiendo muchas cosas. No quiero hijos" (158). 
La angustia se va colando cada vez más en ella: "la desgana habitual, aquella sensación de aceite derramado sin pausa sobre la arena, paralizante, untuosa, me mantenía presa cada vez más a menudo" (168). La distancia con el abismo se acorta: "cuando dejé de comer, cuando me resultó imposible dormir, y ni siquiera escuchaba lo que me decían, y a duras penas soportaba a Chris, decidieron que debía ver a un psicólogo" (172). Pero miente, y no va: "era mi modo de comprar mi libertad y mi independencia, mi derecho a actuar, como los otros, de conservar mis facultades y vivir, pensar, sufrir" (173). Y es el sufrimiento, la angustia, la "enfermedad mortal" ante la posibilidad de la posibilidad, lo que la arrastra hasta la desesperación eterna.

Por otro lado, como Hamlet y la sombra espectral del padre, como Irlanda y la voz de Sagrario y los espíritus de Natalia, o Melocotones helados y el fantasma de Elsita, Diabulus in musica asume desde el inicio lo fantástico como una realidad en sí misma:

Respecto a mí, estoy muerta. Todas las mañanas me levanto, me miro en el espejo y me dedico luego a recorrer la escuela [...]. Mi vida se agotó hace tiempo, y ahora debo conformarme con esta rutina y esta existencia. Un fantasma en un colegio. Balder no hizo sino podar un esqueje muerto (14-15).

La "rutina" evoca una existencia eterna donde solo hay tiempo y silencio. Es cierto que Mikel/Balder solo podó un "esqueje muerto" pues, al igual que él, la protagonista siempre fue un fantasma, casi transparente, "una sombra silenciosa" (31) tras adentrarse en los brazos de la desesperación. Una vez perdido su nombre, Mikel opta por el suicidio. En cuanto a la protagonista, en lucha consigo misma y con lo que se espera de ella, recurre al suicidio tras asimilar el sinsentido de su existencia y la angustia, que materializa en objetos de cristal lanzados en mil pedazos antes de morir. En contra de las advertencias de Kierkegaard, entiende mal la angustia y sucumbe a ella:

Oh, la angustia.

Oh, la angustia.

La angustia es tan grande que mi vida y mi sangre fluyen a través de ella, envenenándome. Ansío encontrar a alguien que cruce por mí este puente, y que tome por mí la decisión que se me hace tan difícil. Este es el comienzo del camino, y me tortura el miedo. Estoy sola, tengo frío. Estoy tan sola. Hace tanto frío. Soy tan pequeña, hay algo enorme que me rodea, y que me engulle, y no puedo moverme, ni siquiera parpadear. La cabeza pesa, pesan las manos, antes tan livianas. 
Ojalá pudiera despertar. Vagamente comprendo que en un momento inmensamente lejano, incomprensiblemente cercano, elegí dormir. Intento recordar las palabras esenciales, las que alejarían las sombras, las que me devolverían al mundo. Socorro. No quise hacerlo. Ayuda. Tengo frío. Tengo miedo. Mamá, mamá, mamá... (182).

Una vez muerta, ella sigue consciente, "viva", pero Chris no la ve. Balder vuelve a por ella y comienzan entonces el tiempo y la angustia eternos:

\begin{abstract}
Siento miedo, una aguja fría recorriendo mi columna vertebral, un recuerdo perpetuo de la culpa. Sé qué penas me causó mientras estuvimos vivos, mientras al menos uno de los dos permaneció vivo. No quiero imaginar de qué torturas es capaz ahora que los dos compartimos oscuridad y frío, ahora que los dos estamos definitivamente muertos, definitivamente vivos (186).
\end{abstract}

Este es el cierre de la novela si bien no el desenlace, ahora que Balder y ella comparten "oscuridad y frío" eternos y las tramas, en lugar de cerrarse, se expanden. En cierto modo ambos se libran de la "muerte infinita", pero para sumirse en una peligrosa existencia eterna, pues, según Kierkegaard, "el tormento de la desesperación consiste exactamente en no poder morirse [...]. Así, estar mortalmente enfermo equivale a no poder morirse, ya que la desesperación es la total ausencia de esperanzas, sin que le quede a uno ni siquiera la última esperanza, la esperanza de morir" (La enfermedad mortal 43). Acaso debido a esto y a que el suicidio materializa la carencia de conciencia del yo, los suicidas espidianos están condenados a vagar eternamente en una búsqueda imposible de su espíritu perdido (ver Rodríguez, "Perversión y muerte..." 343-346).

Cual Ofelia, la protagonista elige la muerte acuática cuando pierde todo referente masculino. Bachelard establece un triángulo entre agua, destino y muerte al que podríamos añadir la angustia, el vertige, la peine: "L'être voué à l'eau est un être en vertige. Il meurt à chaque minute, sans cesse quelque chose de sa substance s'écroule. [...] la mort quotidienne est la mort de l'eau. L'eau coule toujours, l'eau tombe toujours, elle finit toujours en sa mort horizontale. [...] la peine de l'eau est infinie" (9). En el caso del suicidio, Bachelard ofrece importantes aportaciones: "Le suicide, en littérature, se prépare au contraire comme un long destin intime. C'est littérairement, la mort la plus préparée, la plus apprêtée, la plus totale. Pour un peu, le romancier voudrait que l'Univers entier participât au suicide de son héros" (110). Es decir, frente 
al asesinato, el suicidio se convierte en la forma de muerte ideal, marcada por un destino ineluctable: la desaparición. Esto se aprecia en Diabulus in musica, pues sabemos que está muerta desde las primeras páginas pero no cómo muere. Toda la novela es una preparación (una analepsis completa) a la escena de la muerte acuática final.

Así pues, tras cortarse las venas a la manera de los estoicos, la protagonista se sumerge en la bañera: "La sangre que brotó de mis muñecas flotó sobre el agua tibia de la bañera, y luego, con la misma lentitud, como si fuera una medusa abriéndose camino en las cercanías de la costa, como la tinta pesada y bermeja de un calamar, dejó su trazo bajo los grifos. Quise cantar" (180-181). Recuerda entonces el Requiem de Fauré en el aula Paulo VI del Vaticano, también Aitormena ("Confesión") que Mikel tocaba al chelo mientras ella cantaba. Asimismo, vuelve a su boca el libreto del aria final de L'incoronazione di Poppea "Pur ti miro, pur ti godo"9 (181) pero, como en Aitormena, "los buenos tiempos no son para siempre" (84-85 y 181).

A diferencia de Natalia, que termina imponiendo su particular visión del mundo frente a los códigos preestablecidos (ver Rodríguez 2015c, 357-359), la protagonista de Diabulus in musica no soporta el mundo que se le ofrece y cae en otro, en realidad el mismo, pero pérfidamente eterno.

$$
* * * *
$$

Diabulus in musica confirma, pues, nuestro punto de partida: las apariencias, al igual que los sentidos, son engañosos. A veces los instrumentos de placer lo son también de sufrimiento, angustia y mal. Nos deleitamos en la pintura, las historias, la música, pero obviamos -como casi siempre-el largo y doloroso

9 Claudio Monteverdi compuso uno de los dúos de amor y deseo más hermosos de la historia en 1642, meses antes de morir: "Ya te miro/ Ya te gozo/ Ya te estrecho/ Ya te enredo/ Ya no peno/ Ya no muero/ Oh mi vida, oh mi tesoro/ Yo soy tuya.../ Tuyo soy..." Quién diría que antes Nerón, instigado por Popea, mató a su madre, Agripinila, a su maestro, Séneca, a su primera mujer, Octavia, y a todos sus adversarios. Al final, según Tácito, Nerón le dio un puntapié a Popea estando embarazada y la mató. Arrepentido, se enamoró de un esclavo en el que vio cierto parecido con su difunta mujer, lo castró y le obligó a vestirse como mujer, de manera que pudo mantener su particular historia de amor. También en Diabulus in musica nada es como parece, y el dúo de amor esconde el pacto mefistofélico entre Mikel/Balder y la protagonista, entregada incondicionalmente a él por la eternidad. 
camino que esconde el resultado final (años de aprendizaje, perfeccionamiento, sacrificio y obsesión). Pese a los laúdes, arpas, violas, chirimías y tambores, "el infierno musical" no habita más allá de la muerte, está aquí y ahora, y atraviesa sin piedad nuestros oídos con un cuchillo afilado. La angustia, la "enfermedad mortal" kierkegaardiana, es en realidad la protagonista de Diabulus in musica, y sus personajes -unidos por los juegos de (des)amor e identidades y el destino trágico- viven por y para ella. Pero ya sabemos que "el tormento de la desesperación consiste exactamente en no poder morirse" $\mathrm{y}$, por tanto, ni siquiera el suicidio les trae la paz, sino angustia eterna.

Diabulus in musica nos recuerda también que "la música es la ambigüedad erigida en sistema”, pues es la séptima nota, la que ocupa el lugar divino, por donde el diabulus (acaso el daemon meridianus) se desliza y rompe un orden ficticio (a semejanza del sistema de temperamento igual) que nunca existió. La disonancia ofrece la tensión necesaria al discurso estético. Como en la tragedia, como en la vida, los contrarios se unen en una misteriosa armonía.

\section{BIBLIOGRAFÍA}

Arenas, Paula. "Entrevista a Espido Freire". Prensa cuatro, 3 de diciembre de 2003. 18 de enero de 2017. <http://www.espidofreire.com/entr_nosesperalanoche.htm>

Bachelard, Gaston. L'eau et les rêves. 1942. París: Librairie José Corti, 1947.

Brossard-Deconinck, Françoise. “Tempéraments baroques du mal”. Le mal et ses masques. Théâtre, imaginaire, société. Ed. Gisèle Venet. ENS Éditions: Fontenay-aux-Roses, 1997. 251-265.

Davies, Martin. “Uccello's St. George in London”. The Burlington Magazine 101 (1959): 309-316.

Freire, Espido. Primer amor. Madrid: Temas de Hoy, 2000.

Diabulus in musica. Barcelona: Planeta, 2001.

"El mal en mi obra". Conferencia a cargo de Espido Freire en el Colegio de España de París, presentada y organizada por Samuel Rodríguez con la colaboración de la Universidad Paris-Sorbonne (École Doctorale IV y CRIMIC). 2015. 18 de enero de 2017. <http://www. dailymotion.com/video/x3i8qwp_conference-de-1-ecrivaine-espido-freire-i_creation>.

García Galiano, Ángel. "La nueva narrativa bilbaína ante el tercer milenio: Espido Freire". Bilbao. El espacio lingüístico. Simposio 700 Aniversario. Eds. Ana Elejabeitia Ortuondo y Juan Otaegi. Bilbao: Universidad de Deusto, 2002. 455-463.

García Jambrina, Luis. "El diablo en la novela". ABC Cultural 2 de enero de 2002: 10. 
Gómez-Elegido Centeno, Ana María. "Voces y presencias femeninas en la literatura de Espido Freire". Letra de mujer. Eds. Milagros Arizmendi Martínez y Guadalupe Arbona Abascal. Madrid: Ediciones del Laberinto, 2008. 1-29.

"Las huellas de la posmodernidad en la obra de Espido Freire: Diabulus in musica". Literatura de la posmodernidad. Madrid: Fragua, 2009. 241-261.

Grout, Donald Jay y Claude Victor Palisca. Historia de la música occidental. 1960. Vol. 1. Madrid: Alianza, 2002.

Henseler, Christine. "Del bien y del mal. Una entrevista con Espido Freire". Letras peninsulares 17 (2004): 249-258.

Herrero Cecilia, Juan. "Figuras y significaciones del mito del doble en la literatura: teorías explicativas". Cédille. Revista de estudios franceses 2 (2011): 17-48.

Kierkegaard, Søren. El concepto de la angustia. 1844. Madrid: Espasa Calpe, 1959.

La enfermedad mortal. 1849. Madrid: Sarpe, 1984.

Linares, Montserrat. "Fragmented Identities: The Narrative World of Espido Freire". Women in the Spanish Novel Today. Eds. Kyra Kietrys y Montserrat Linares. Jefferson N.C.: McFarland, 2009. 205-218.

Mann, Thomas. La muerte en Venecia, La montaña mágica, Doctor Faustus. 1912. 1924. 1947. Barcelona: Plaza \& Janés, 1996.

Martín Gaite, Carmen. Desde la ventana. Enfoque femenino de la literatura española. 1987. Madrid: Espasa Calpe, 1993.

Page, Raymond Ian. Mitos nórdicos. Madrid: Akal, 1992.

Pozuelo Yvancos, José María. Desafíos de la teoría. Literatura y Géneros. Mérida: El otro mismo, 2007.

Rodríguez, Samuel. "Espido Freire y la renovación del cuento literario español: Aspectos teóricos y estético-formales". Revista Internacional de Estudios Vascos 59.2 (2014): 396-419. 18 de enero de 2017. <http://www.euskomedia.org/PDFAnlt/riev/59/RIEV 59_2_398-422.pdf>

"Perversión y muerte como fundamentos narrativos en la obra de Espido Freire". La tragedia del vivir: dolor y mal en la literatura hispánica. Eds. Ricardo de la Fuente Ballesteros, Jesús Pérez Magallón y Francisco Estévez. Valladolid: Verdelís, 2014. 339-348.

"Voces y espejos de Espido Freire. Hacia una estética de la perversión en el relato especular”. Acta Hispánica 19 (2014): 51-62. 18 de enero de 2017. <http://publicatio. bibl.u-szeged.hu/5035/1/Katona\%20ActaHispanica2014.pdf>

"Hacia los orígenes del mal. Violencia simbólica y personajes femeninos en la narrativa de Espido Freire". Iberic@l 8 (2015a): 133-148. 18 de enero de 2017.<http:// iberical.paris-sorbonne.fr/wp-content/uploads/2015/12/Iberic@1-no8-automne-2015-op.pdf>

"Le conte de fées comme catalyseur du mal dans l'oeuvre d'Espido Freire". Gradiva. Réflexions sur les créations au féminin. Pau: Universidad de Pau, 2015b. 18 de enero de 2017.<http://gradiva.univ-pau.fr/live/digitalAssets/139/139282_Les_contes_de_f_es_ comme_catalyseurs_du_mal.pdf>

"Trauma y opresión como mecanismos de construcción de la identidad femenina (perversa) en Irlanda de Espido Freire”. ¿Decir lo indecible? Traumas de la historia y las historias del trauma en las literaturas hispánicas. Eds. Dominika Jarzombkowska y 
Katarzyna Moszczynska-Dürst. Varsovia: Instituto de Estudios Ibéricos e Iberoamericanos de la Universidad de Varsovia, 2015c. 347-366. 18 de enero de 2017. <http://www. academia.edu/16722561/Dominika_Jarzombkowska_Katarzyna_Moszczy\%C5\%84skaD\%C3\%BCrst_eds._Decir_lo_indecible_Traumas_de_la_historia_e historias_del_trauma en_las_literaturas_hisp $\% \bar{C} 3 \%$ A 1 nicas._Varsovia_Biblioteka_Iberyjska_Instituto_de Estudios_Ib\%C3\%A9ricos_e_Iberoamericanos_de_la_Universidad_de_Varsovia_2015> Rodríguez Fisher, Ana. "Tres en discordia”. Babelia (suplemento de El País) 5 de enero de 2002: 8 .

Shakespeare, William. Dramas. Comedias. Barcelona: Nauta, 1967.

Sierra del Molino, Rosa María. "El Ragnarök: ¿el final de los tiempos? Apocalipsis o el destino de las potencias en el universo mitológico nórdico". Arys 10 (2012): 127-146.

Todorov, Tzvetan. Introduction à la littérature fantastique. París: Seuil, 1970.

Vattimo, Gianni. El sujeto y la máscara. Nietzsche y el problema de la liberación. 1974. Barcelona: Península, 1989.

Vega, Lope de. El caballero del Olmedo. 1641. Madrid: Cátedra, 1984. 